\title{
TRI PARADIGME NOVODOBNEGA RAZVOJA SLOVENSKIH MEST
}

\author{
Vladimir Drozg \\ Univerza v Mariboru, Filozofska fakulteta, Oddelek za geografijo, Koroška cesta 160, \\ SI-2000 Maribor, Slovenija \\ e-mail: vlado.drozg@uni-mb.si
}

Izvirni znanstveni članek

COBISS 1.01

\begin{abstract}
Prispevek obravnava tri paradigme prostorskega razvoja mest v Sloveniji, in sicer: vrtno mesto, sosesko in fraktalno mesto, z namenom primerjati jih med seboj in spoznati ustroj mest, kakršen je nastal ob implementaciji posameznega koncepta. Ugotovitve slonijo na primerjavah treh stanovanjskih območij v Mariboru, Ravnah na Koroškem in v Ljubljani.
\end{abstract}

Key words: morfologija mest, paradigma, vrtno mesto, soseska, fraktalno mesto.

\section{THREE PARADIGMS OF MODERN DEVELOPMENT OF SLOVENIAN TOWNS}

\section{Izvleček}

This contribution discusses three paradigms of spatial development of Slovenian towns, namely: garden town, outskirts and fractal town. The intention of this approach was comparison of towns with each other, as well as familiarization with their structure that originated through implementation of the individual concept. Findings are based on comparisons of three residential areas in Maribor, Ravne na Koroškem and Ljubljana.

Ključne besede: morphology, paradigm, garden city, neighbourhood, fractal city. 


\section{UVOD IN NAMEN PRISPEVKA}

V začetku 20. stoletja se je v industrijskih državah Evrope nakazoval prelom v urejanju mest in stanovanjskih območij. Množično priseljevanje je vzpodbudilo razmišljanja o tem, kako nova stanovanjska območja zasnovati. Dotedanji način urejanja je postajal preozek za številne potrebe, ki so se pojavljale v socialno vse bolj heterogenem urbanem konglomeratu in na industriji temelječem gospodarstvu. $\mathrm{S}$ tem se je odprl prostor idejam in zamislim o idealnem bivanju, ekonomičnih stanovanjskih enotah ter ustroju mest nasploh. 50 let pozneje so bile podobne razmere v Sloveniji. Načrtovalci stanovanjskih sosesk so v veliki meri sledili preizkušenim in tudi aktualnim tujim vzorom. Vendar so se zamisli konceptualno razlikovale med seboj; ne le zaradi različnih obdobij v katerih so nastale, razlikovale so se tudi v razumevanju funkcije bivanja (stanovanja) in, posredno, vsebine mesta. Na tej točki postane tematika geografsko relevantna. Po eni strani kot kulturno geografska snov v okviru historične urbane geografije, po drugi strani kot medij spoznavanja fizične zgradbe mesta.

Namen prispevka je, na podlagi analize treh stanovanjskih območij, izgrajenih v različnih obdobjih in po različnih konceptih, prikazati značilnosti paradigem prostorskega razvoja mest v 20. stoletju in, posredno, prikazati ustroj mest v posameznih obdobjih. Težišče prispevka ni na historiatu idej o urejanju mest, temveč na spoznavanju morfoloških značilnosti, ki so rezultat teh zamisli. Ne gre niti za prikaz posameznih primerov, temveč je študij primerov zgoj sredstvo za razkrivanje globlje ideje, ki se za obliko skriva.

Ob tem še nekaj pojasnil: snov, ki jo obravnavamo, nima prav dosti »opornih točk«. V geografski literaturi je slabo proučena, v literaturi iz področja urbanizma in arhitekture pa je zelo avtorsko obarvana. Oris paradigem nikakor ne more biti celovit in dokončen, saj je tematika veliko preobsežna in, kar je najpomembnejše, dovoljuje veliko najrazličnejših interpretacij. S prispevkom želimo prikazati način interpretacije fizične strukture mest ter prispevati k utrjevanju terminologije iz tega področja.

\section{PARADIGME NOVODOBNEGA UREJANJA MEST}

Najprej kratko pojasnilo pomena besede »paradigma«: pojem izvira iz lingvistike, kjer pomeni »vzorec, zgled za sklanjatev ali spregatev« (Verbinc 1967, 522). Poanta besede je torej v določenem načinu, ki služi kot zgled za ostale. Podobno je pojem razumljen v filozofiji, in sicer kot nekaj izvornega, trajnega, sorodna pojmu bistvo, za razliko od tistega »zunanjega «, ki pa je spemenljivo in minljivo (MPL 1999, 426). Nekoliko prirejeno razumevanje (po Kuhnu) pojma pravi, da gre za splošno veljavna spoznanja (dosežke), ki, po mnenju določene skupine strokovnjakov, ponujajo boljše rešitve (razumevanje) določenega problema, od drugih. V tem smislu uporabljamo pojem tudi v pričujočem prispevku; paradigma pomeni način izgradnje mesta in stanovanjskega območja, ki je v določenem obdobju najbolje ustrezal razmeram in razumevanju obeh pojmov - mesto in stanovanje. Paradigme niso teorije, temveč iz teorij izhajajoče interpretacije najpomembnejših povdarkov.

V novejši zgodovini urbanističnega urejanja se, kot smo že omenili, pojavlja več konceptov - paradigem. V pričujočem prispevku smo izbrali tri, za katere menimo, da so za slovenska mesta najrelevantnejše; pravzaprav so najbolj značilne za tri faze prostorskega 
razvoja mest v Sloveniji. To so: dograjevanje obstoječe grajene strukture med leti 1920 in 1950, ekspanzija na nove površine med leti 1950 in 1990 in zapolnjevanje po letu 1990.

\section{Paradigma vrtnega mesta}

Ideja vrtnega mesta je nastala v Angliji konec 19. stoletja kot reakcija na nezdrave, že kar bedne stanovanjske razmere, v kakršnih so bivali delavci, ki so se preselili v mesta. Majhna, vlažna, nezdrava stanovanja so bila leglo številnih bolezni, pa tudi socialnih nemirov. Ebenzer Howard je leta 1898 predstavil zamisel o »mestu« v zeleni okolici, v bližini ali na robu »pravega« mesta, $\mathrm{z}$ nizko gostoto stanovanj ter $\mathrm{z}$ dejavnostmi v bližini, ki zadovoljujejo osnovnim potrebam prebivalcev. Vrtno mesto tvorijo tipizirani stanovanjski objekti, vsak objekt ima ohišnico, na območju je javna odprta površina s socialno funkcijo. V 20-tih letih prejšnjega stoletja je prišlo do modifikacije prvotne ideje, najprej nekakšna prilagoditev »uličnemu bloku«, ki je morfološki element klasicističnega mesta iz konca 19. stoletja, kasneje pa funkcionalistično pojmovani soseski.

\section{Paradigma stanovanjske soseske}

V času med obema vojnama je na snovanje mest močno vplivala ideja funkcionalizma, ki izpostavlja delitev mesta na območja prevladujočih dejavnosti. Ideja se je »obrusila« v teoriji namenske rabe zemljišč, ki se je pojavila na prehodu v 20. stoletje ter z Atensko listino leta 1933 dobila potrditev strokovne javnosti. Funkcionalistično zasnovano mesto je razdeljeno na območja namenske rabe, med seboj so ločena $\mathrm{z}$ zelenimi cezurami, prometnicami, nevtralnimi prostori. Ločevanje območij po namembnosti (npr. dela in bivanja) je vzrok intenzivnim prometnim tokovom, zaradi česa postane promet eden od ključnih sistemov v mestu. Funkcionalizem ima še eno značilnost: v prevladujoči tehnični kulturi tistega časa, mimogrede, tudi stanovanje je bilo razumljeno kot »stroj za bivanje«, je prevladovalo geometrijsko razmeščanje stanovanjskih objektov, ti so bili tipološko enaki, njihovo zasnovo je določala množica normativov (o osončenju, višini, primerni površini bivalnega prostora). Združeni so bili v stanovanjsko sosesko, zaključeno območje, prilagojeno dnevnim potrebam družine in otrokom (Mušič 1980, 262).

\section{Paradigma (urbanih) fraktalov}

Po letu 1990 se je ekspanzivno širjenje mest na nove površine v okolici upočasnilo, deloma zaradi intenzivne suburbanizacije, predvsem pa so se spremenili pogoji za stanovanjsko gradnjo. Nekdanja državna podjetja in paradržavne ustanove, ki so financirale izgradnjo stanovanj, v tržnem gospodarstvu ne delujejo več. Za investitorje so postale zanimivejše manjše lokacije, kjer lahko ob maksimalni gostoti in izkoristku zemljišča, stanovalcem ponudijo največ bivalnega udobja, ki ga prostor prenese. V tako imenovanem projektnem financiranju se je tudi zaradi omejenega prostora uveljavilo zapolnjevanje prostih površin - enklav (gl. Lobnik, 2006, Drozg, 2004). Tak pristop ima tudi teoretsko podlago. Teorija fraktalov opisuje lastnost nekaterih delcev kot samopodobnost, kar pomeni, da so enaki (podobni, imajo enake lastnosti) tudi kadar jih opazujemo v različnem merilu (tehnično: na vseh razdaljah; www.kvarkadabra.net). Asociacija z mestom ponazarja podobnost morfoloških elementov v celotnem mestu, v delu mesta, mestni četrti, ulici, stavbnem otoku; povsod se pojavljajo isti 
morfološki elementi. Povedano drugače: ureditev posameznega območja (enklave) obsega vse elemente, ki jih poseduje mesto - objekte, prometnice, odprte površine, javne in zasebne površine, objekte za delo, bivanje, oskrbo. Stanovanjsko območje je torej »mesto v malem«, opremljeno s tistim, kar pritiče njegovi velikosti.

$\mathrm{Ob}$ opisanih paradigmah nastajajo različni prostorski vzorci in ustroj mest. Prva paradigma gradi na vzpostavljanju uličnega bloka in obcestne zazidave, druga na morfološko in funkcijsko zaključenem območju - delu mesta, tretja na enklavi, omejeni, zaključeni površini znotraj grajene strukture.

\section{METODOLOŠKI NASTAVKI - KAJ PRIMERJATI IN KAKO SPOZNAVATI}

Poanta urbanogeografskega spoznavanja paradigem razvoja mest ni v opisovanju tlorisa posameznih območij (primerov), temveč $\mathrm{v}$ razkrivanju ideje in splošnih značilnosti, po kateri je stanovanjsko območje zasnovano. $V$ tem kontekstu je posebej pomembno razmerje med območjem in okolico ter morfološke značilnosti obravnavanega območja.

Paradigme je možno primerjati na dveh ravneh, pri čemer so vprašanja, ki si jih zastavljamo, naslednja:

Na ravni celotnega mesta oziroma dela mesta

- ali obstaja prostorski ali funkcijski odnos med stanovanjskim območjem in celotnim mestom, kateri so bistveni elementi tega odnosa, kakšen je odnos do historične dediščine mesta?

- $\quad$ kateri predstavi, idealu, sledi posamezna paradigma, kaj je njeno bistvo ?

- $\quad$ kako se posamezna paradigma vključuje v prostorsko rast mesta ?

Na ravni območja in bližnje okolice

- $\quad$ ali razmestitev objektov sledi morfološkemu vzorcu bližnje okolice?

- $\quad$ katerim socialnim potrebam je na območju zadovoljeno ?

- kakšno je razmerje med zasebnim in javnim prostorom, čemu so namenjene odprte površine?

Spoznavanja paradigem smo se lotili s študijem gradiv o izbranih območjih, zapisov, načrtov, fotografskega materiala, dalje, s terenskimi ogledi, s čemer smo skušali nadgraditi poznavanje zgodovine in teorije urbanizma ter morfologije mest. Bolj kot analitičen pristop smo uporabljali sintezo, povezovanje različnih dejstev in na podlagi tega, oblikovanje novih spoznanj.

\section{KRATEK PRIKAZ OBRAVNAVANIH OBMOČIJ}

\section{Vurnikovo naselje (Maribor)}

Leta 1927 je mestna oblast $v$ predelu Tabor organizirala in sofinancirala izgradnjo socialnih stanovanj za trg. Nastalo je stanovanjsko območje, ki se po načrtovalcu Ivanu Vurniku imenuje Vurnikovo naselje. Tvori ga 147 objektov, ki so združeni v 10 nizov s po 24 oziroma 8 objekti. 
Štirje nizi objektov so razmeščeni po obodu dveh uličnih blokov, šest krajših pa zapolnjuje notranjost uličnih blokov. Takšna razmestitev je povsem v maniri izgradnje mest iz začetka 20. stoletja, ko je, vsaj na slovenskih tleh, še prevladovala ideja klasicističnega mesta z ortogonalno mrežo prometnic in uličnim blokom kot tipološko enoto. Posledica tega je zazidanost, za katero še danes velja, da je zelo urbanotvorna. Pomeni namreč strnjeno zazidavo s tipološko enakimi objekti, ki obdajajo obe strani prometnice. Obodne prometnice krasi drevored, kar je predvsem oblikovni element.

\section{Slika 1: Vurnikovo naselje v Mariboru (foto V.D.)}

Figure 1: The Vurnik settlement in Maribor (photo V.D.)
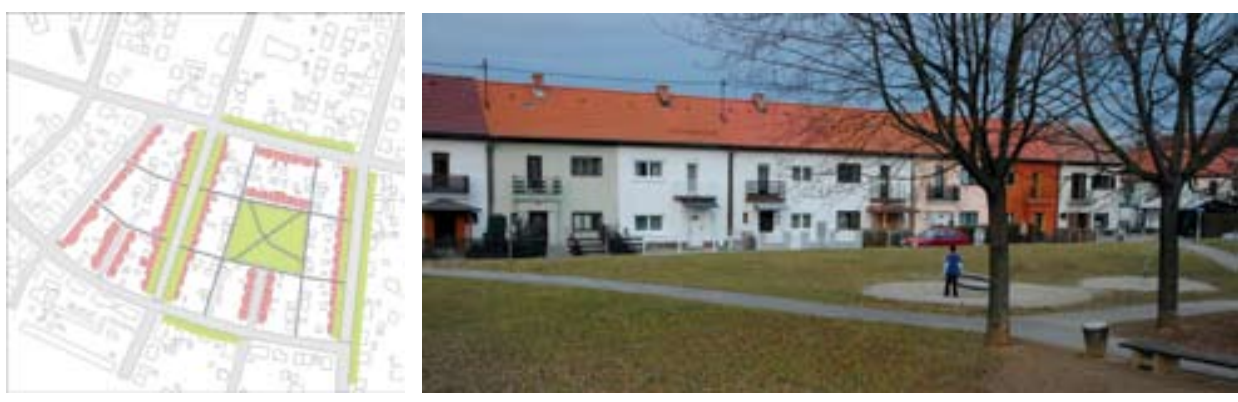

Razmestitev objektov je posledica ortogonalno zasnovane prometne mreže, ob kateri so v nizu razporejeni objekti. Omeniti še velja, da je bilo širše območje, kjer je v letih 1927 - 1929 zraslo naselje enodružinskih hiš, nepozidano. Sredi večjega uličnega bloka je urejen park, na novo je urejeno še otroško igrišče, ki ga prvotno ni bilo. Park ima pravilen, simetrični tloris, po diagonali ga prečkata dve poti, na sredi pa je rondo s klopmi za posedanje. Zelena površina ima pol javni značaj, v prvi vrsti je namenjena prebivalcem naselja; nekdaj so stanovalci tod pripravljali skupna praznovanja in družabne igre.

V naselju ni oskrbnih in storitvenih dejavnosti, kar bi lahko pomenilo, da območje ni bilo zasnovano kot zaključena (zaprta) enota, temveč kot del predela mesta. V bližini se nahaja cerkev, osnovna šola, trgovina in gostilna, vendar so te dejavnosti namenjene prebivalcem širšega območja. Stanovanjski objekti so zelo skromnih dimenzij, $38 \mathrm{~m}^{2}$ po etaži. K vsaki enoti sodi še ohišnica z vrtom. Hiša ima dva vhoda, sprednjega, iz glavne prometnice, in zadnjega, iz vrta. Med ohišnico je speljana pot, ki povezuje stanovanjske objekte. Javni, zasebni in poljavni prostor je jasno ločen.

Temelj takšne zasnove je, po našem mnenju, ustvarjanje urbanosti ter primernih, vendar enakih bivalnih razmer.

\section{Stanovanjska soseska Javornik (Ravne na Koroškem)}

Stanovanjsko območje Javornik se nahaja na robu Raven, približno 300 m od mestnega središča. Zasnovano je bilo leta 1967, izgrajeno pa med leti 1972 in 1988. Po prvotnem načrtu je soseska obsegala 14 različno velikih stanovanjskih enot, razmeščenih po robu velikega platoja. Takšna razmestitev ustvarja veliko zeleno površino sredi stanovanjske soseske, katere 
namembnost je v prvi vrsti socialna. Na njej so urejena otroška igrišča, klopi za posedanje, pred bloki so mestoma parkirišča. Na zunanji strani stanovanjskih objektov je obodna prometnica, s katero so objekti povezani med seboj in z mestom. S tem je dosežena ločitev dinamičnega od mirujočega prometa ter ločitev površin za motorni promet in za pešce kar bi naj še povečalo atraktivnost osrednje zelenice. Konec 80-tih let sta bila izgrajena še dva objekta, in sicer na sredini soseske, kar je prvotno ureditev nekoliko spremenilo. Velika osrednja nepozidana površina je sedaj razbita $v$ več manjših, zaradi povečane motorizacije je del zelenice spremenjen $\mathrm{v}$ parkirišča.

V stanovanjski soseski je osnovna šola, otroški vrtec in samopostrežna trgovina. $\mathrm{V}$ tem pogledu je soseka samozadostna, saj lahko prebivalci dnevne potrebe zadovoljujejo v bližini kraja bivanja. Urbana oprema na osrednjem odprtem prostoru je skromna. Razen otroških igrišč, klopi in dveh skulptur, je osrednje območje zgolj odprti prostor. Ob soseski je več duplex garaž. Soseka je dimenzionirana na okoli 10.000 prebivalcev.

Zasnova soseske se ne zgleduje po morfološkem vzorcu bližnje okolice, ki resda ni gosto poseljena. Vendar se tudi morfološki vzorec bližnjega mesta ne odraža v zasnovi soseske. Prej nasprotno - velik volumen stanovanjskih blokov je izrazito dominanten in terja prilagajajnje drugih grajenih struktur. Ob soseski je dvorec Javornik, ki je simbolno pomemben objekt tega območja. V morfološki zasnovi soseske bližine simbolno tako pomembnega objekta ne opazimo, s čemer je njegova pojavnost okrnjena, pričevalnost pa zmanjšana.

\section{Slika 2: Soseska Javornikv Ravnah na Koroškem (foto V.D.)}

Figure 2: The Javornik neighbourhood in Ravne na Koroškem (photo V.D.)
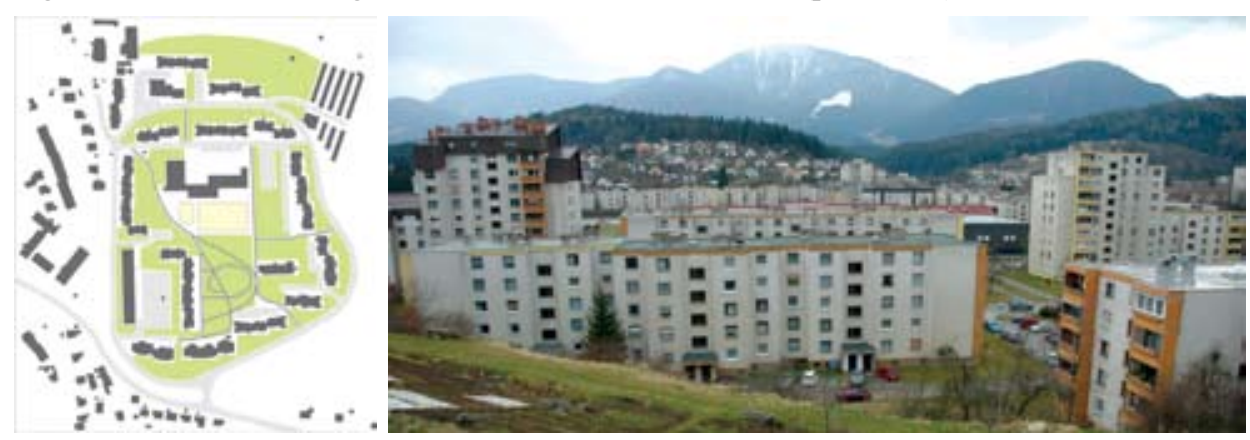

Povezave $\mathrm{z}$ okoliškim prostorom so razpoznavne v obliki objektov. Gabarit blokov postopoma raste od $\mathrm{P}+4$ do $\mathrm{P}+10$, kar asociira na silhueto okoliških hribov. Tudi razmak med posameznimi objekti je premišljen do te mere, da vmesne praznine omogočajo razgled po okolici, kar bi naj povečalo občutek povezanosti soseske z naravnim okoljem.

Razmestitev objektov vzbuja vtis prostorske zaokroženosti, vzpostavljanjem osrednjega prostora, hkrati pa vtis monumentalnosti in drugačnosti od starega mesta. Oboje je v duhu takratnega časa - ustvarjanje enakih bivalnih razmer za vse prebivalce, povdarjanje kolektivnosti, prelom s preteklostjo. Objekti so razmeščeni v težko berljivem redu. Osnovni vzorec je enostaven - ob robu platoja si v nizu, vendar zamaknjeno, sledijo stanovanjski 
objekti. Ob vhodu v sosesko ter na treh skrajnih točkah so objekti višji $(P+10)$ - vizualni povdarki, ki označujejo rob soseske.

\section{Stanovanjsko naselje Stožice (Ljubljana)}

Ob zgornjem delu Dunajske ceste je na približno $8000 \mathrm{~m}^{2}$ velikem zemljišču v letih 1998 - 2000 nastal poslovno stanovanjski objekt, katerega umestitev v prostor nakazuje novo paradigmo prostorskega razvoja mest. Območje je »utesnjeno« med Dunajsko cesto in ježo terase oziroma kmetijska zemljišča na vzhodni strani. Enklavo zapolnjuje več objektov, in sicer en daljši objekt v obliki črke L, postavljen vzporedno z Dunajsko cesto, na katerega se na notranji strani (vstran od prometnice) navezuje 6 , v parih postavljenih manjših stanovanjskih stolpičev. Na obcestni strani največjega objekta je parkirišče, po notranjem delu pa motorni promet ni mogoč. Pač pa je tod urejena peš pot, dostopi do podzemnih garaž, majhen trg $\mathrm{s}$ fontano (v kletni etaži), zelenice, ponekod tudi zasebna zelenica, ki pripada stanovanjem v pritličju.

\section{Slika 3: Poslovno stanovanjski objekt Stožice v Ljubljani (foto V.D.)}

Figure 3: A business-residential object Stožice in Ljubljana (photo V.D.)
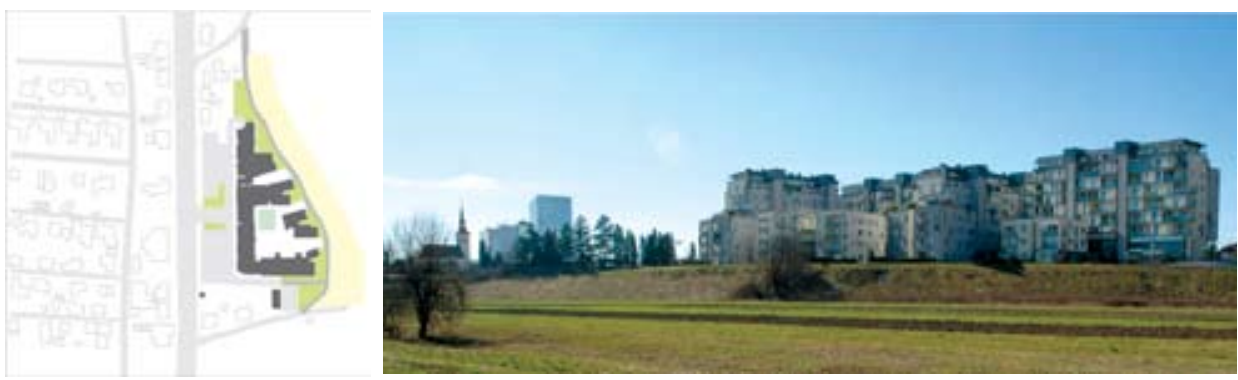

Zasnova stanovanjskega območja daje vtis skrajno racionalne izrabe razpoložljivega prostora. Stavbna parcela je povsem izkoriščena. Ker se nahaja znotraj grajene strukture, jo imenujemo enklava. Ker so na zemljišču prometne površine, javne površine, stanovanja, delovna mesta, okrasne zelene površine, pol javni prostor, ki asociira na trg, imenujemo takšna območja urbani fraktali. Stanovanjski objekt ima dva »obraza«. Obulična fasada je enovita, notranja pa je zelo razgibana. Objekti so mestoma zelo tesno drug ob drugem, gabarit je $\mathrm{P}+4$ do $\mathrm{P}+8$. Fasada majhnih stolpičev je zelo razgibana, s številnimi izzidki in zatoki. Morfološki vzorec okolice pri zasnovi območja ni upoštevan, niti višina sosednjih objektov, niti tipologija. Res pa ob Dunajski cesti nastaja več novih stavbnih kompleksov, ki so tipološko podobni.

Na območju prevladujejo stanovanja, v parterju in v odprti kletni etaži največjega objekta so poslovni prostori za različne storitvene dejavnosti. Le te niso namenjene stanovalcem, temveč prebivalcem širše okolice (med njimi ni trgovine $\mathrm{z}$ živili). Razmerje med javnim in zasebnim prostorom gre povsem v prid javnega oziroma pol javnega. Pravzaprav zasebnega prostora na območju ni, razen za stanovalce v pritličju stolpičev, ki uporabljajo zelenico ob stanovanju. Med objekti in na vzhodnem robu kompleksa je urejena pol javna površina, nekakšna sprehajalna pot. 
Podoba stanovanjskega kompleksa je zelo vpadljiva, k čemur prispevajo sodobni materiali (kovina, steklo), atraktivna arhitektura objektov, pa tudi stik med grajenim in naravnim okoljem.

\section{PRIMERJAVA MED OBMOČJI IN PARADIGMAMI}

V nadaljevanju prikazujemo obravnavane paradigme v medsebojni primerjavi. Pri tem ne gre za zgodovinski oris širjenja mest, niti za primerjanje značilnosti posamezih območij, temveč za primerjavo idej, katerih rezultat je različen ustroj stanovanjskih območij iz posameznih obdobij prostorskega razvoja mest. $\mathrm{V}$ treh paradigmah lahko vidimo lok med tradicionalnim stavbarstvom, kakršno pooseblja klasicistično mesto z idejo »genius loci«, ter moderno, ki pomeni nov način urejanja in pojmovanja mesta, kjer so vezi s stavbno dediščino manj prepoznavne ali pa sploh ne obstajajo (tako imenovani »non-place urban realm«).

Tabela 1: Primerjava med območji in paradigmami na ravni celotnega mesta oziroma dela mesta Table 1: A comparison between areas and paradigms at the level of a whole city or part of a city

\begin{tabular}{|l|l|l|l|}
\hline & Vurnikovo naselje & Javornik & Stožice \\
\hline $\begin{array}{l}\text { Morfološke } \\
\text { značilnosti }\end{array}$ & $\begin{array}{l}\text { Niz enodružinskih hiš, } \\
\text { razmeščnih v uličnem } \\
\text { bloku, zaokroženost } \\
\text { območja. }\end{array}$ & $\begin{array}{l}\text { Prostostoječi objekti } \\
\text { razmeščeni v repetitivnem } \\
\text { vzorcu okoli zelene } \\
\text { površine. }\end{array}$ & $\begin{array}{l}\text { Solitarni objekti umeščeni } \\
\text { v drugačen morfološki } \\
\text { vzorec. }\end{array}$ \\
\hline $\begin{array}{l}\text { Funkcijske } \\
\text { značilnosti }\end{array}$ & $\begin{array}{l}\text { Stanovanjsko območje } \\
\text { brez oskrbnih dejavnosti, } \\
\text { v funkcijskem smislu } \\
\text { odvisno od središčnega } \\
\text { dela mesta. }\end{array}$ & $\begin{array}{l}\text { Osnovne dejavnosti z } \\
\text { možnostjo dopolnjevanja. }\end{array}$ & $\begin{array}{l}\text { prebivalcem širšega } \\
\text { predela mesta, } \\
\text { polifunkcijsko območje. }\end{array}$ \\
\hline $\begin{array}{l}\text { Prostorska } \\
\text { rast } \\
\text { mesta }\end{array}$ & $\begin{array}{l}\text { Organska rast mesta po } \\
\text { uličnih karejih. }\end{array}$ & $\begin{array}{l}\text { Ekspanzivna rast mesta z } \\
\text { dodajanjem novih sosesk. }\end{array}$ & $\begin{array}{l}\text { Introvertirana rast mesta } \\
\text { zapolnjevanjem in } \\
\text { prestrukturiranjem prostih } \\
\text { ali degradiranih območij. }\end{array}$ \\
\hline $\begin{array}{l}\text { Odnos do } \\
\text { grajenih } \\
\text { struktur v } \\
\text { okolici }\end{array}$ & $\begin{array}{l}\text { Razpoznavna vez s } \\
\text { klasicističnim mestom in } \\
\text { morfološkim vzorcem. } \\
\text { Vključenost v sistem } \\
\text { prometne mreže. }\end{array}$ & $\begin{array}{l}\text { Nov morfološki vzorec, } \\
\text { brez povezav s historičnimi } \\
\text { grajenimi strukturami. }\end{array}$ & $\begin{array}{l}\text { Brez odnosa do historične } \\
\text { grajene strukture, nov } \\
\text { morfološki vzorec. }\end{array}$ \\
\hline
\end{tabular}

\section{Morfološke značilnosti: celota in njeni sestavni deli}

Klasicistično mesto je (bilo) kompaktno naselje. Širjenje je sledilo rastru prometnic, zaradi česar je mesto rastlo korak za korakom od središča navzven. Razmestitev in tipologija objektov sta bila znana - ulični blok, ki ga obdajajo večstanovanjske meščanske hiše, delavske hiše ali vile. $\mathrm{Ob}$ tem je nastajal pozidan prostor, nepozidane površine so bile predvsem komunikacijske poti in odprte javne površine s socialno funkcijo. 
$\mathrm{Z}$ nastankom soseske se je ustaljen koncept spremenil: soseske niso nastajale ob prometnicah, pač pa na robu mesta, kjer je bilo dovolj veliko stavbno zemljišče. Kontinuiteta z gradbenim razvojem je bila prekinjena, posledica je nastanek manj kompaktnega mesta, kjer so posamezni stanovanjski predeli manj povezani med seboj. Novo mesto je razdeljeno na soseske, ki niso povezane v enotno stavbno tkivo. Ne le da so morfološko različnih vzorcev, tudi orientirane so navznoter, ne pa povezane $\mathrm{z}$ okolico in, kar je še posebej pomembno, $\mathrm{v}$ večji meri ustvarjajo odprti, ne pa grajeni prostor.

V času, ko se je intenzivnost stanovanjske gradnje zmanjšala, so se mesta, vsaj kar se novih površin tiče, začela izgrajevati manj velikopotezno. Gradnja »mest v malem«, pozidava enklav, je koncept razvoja v 90-tih. Tak koncept ustvarja mozaično strukturo mest. Odnos do obstoječe grajene strukture je skoraj irelevanten, razpoznaven je odnos do bližnje okolice, vendar bolj v smislu nadgrajevanja, kakor prilagajanja.

\section{Dejavnosti v mestih}

Klasicistično mesto je v bistvu centralistično zasnovano; večina dejavnosti je bila v srednjeveškem jedru, v stanovanjskih območjih pa le redke oskrbne dejavnosti. Funkcionalistično mesto in ideja soseske temelji na drugačnih izhodiščih: stanovanjska območja so samozadostne enote $\mathrm{z}$ osnovnimi oskrbnimi in storitvenimi dejavnostmi. Mesto je bilo decentralizirano, storitve so se približale uporabnikom. Povsem drugačno je mesto fraktalov: Stožice so stanovanjsko območje s funkcijami, ki niso namenjene stanovalcem, temveč prebivalcem širšega območja, pravzaprav prebivalcem celotnega mesta. Socialna heterogenost prebivalcev in nove oskrbovalne navade so vzrok drugačni razmestitvi oskrbnih dejavnosti v mestu, ki so skoncentrirane večinoma $v$ trgovskih središčih. Hkrati pa opažamo vse večji preplet storitvenih in poslovnih dejavnosti v stanovanjskih območjih, kar imenujemo polifunkcionalnost. Čistih stanovanjskih območij brez delovnih mest, v sodobnih mestih skoraj ni več.

\section{Širjenje mesta: kontinuiteta ali prelom}

Opisane paradigme je potrebno videti v kontekstu razvoja celotne družbe, saj je mesto samo njen derivat. In $\mathrm{v}$ tem kontekstu vse obstoječe izhaja iz predhodnega. Vurnikovo naselje je zasnovano v maniri klasicističnega mesta, čeprav stavbna enota ni večstanovanjska meščanska hiša, temveč enodružinska (delavska) hiša (zato govorimo o vrtnem mestu). Ulični blok in postavitev $\mathrm{v}$ nizu ohranjata vez $\mathrm{s}$ takrat prevladujočim načinom gradnje. Drugače je pri naselju Javornik: razmestitev in tip objektov pomenita revolucionarno novost tako glede umestitve v prostor, kot glede tipologije objektov. Paradigma soseske pomeni prekinitev vezi s klasicističnim mestom in uvajanje novega morfološkega vzorca, kjer sta grajeni in odprti prostor enakovredna. Razkorak med fraktalno strukturo sodobnega mesta in funkcionalističnimi soseskami je še očitnejši. Nove enklave so mesta v malem, individui, kakršna postaja sodobna družba. Vezi z okolico so minimalne, večinoma omejene samo na najnujnejši prometni priključek. V primerjavi s paradigmo uličnega bloka in soseske, se sodobni razvoj mest omejuje na posamezne nukleuse, zapolnjuje mestni prostor in ga s tem gradi. 
Tabela 2 : Primerjava med območji in paradigmami na ravni na ravni območja in bližnje okolice Table 2: A comparison between areas and paradigms at the level of a region and the nearby surroundings

\begin{tabular}{|l|l|l|l|}
\hline & Vurnikovo naselje & Javornik & Stožice \\
\hline $\begin{array}{l}\text { Osnovna ideja } \\
\text { paradgme }\end{array}$ & $\begin{array}{l}\text { Racionalna izraba } \\
\text { zemljičč in enakost } \\
\text { bivalnih pogojev. }\end{array}$ & $\begin{array}{l}\text { Socialna preglednost in } \\
\text { možnost zadovoljevanja } \\
\text { osnovnih potreb znotraj } \\
\text { bivalnega okoliša. }\end{array}$ & $\begin{array}{l}\text { Optimalna izraba } \\
\text { razpoložljivega zemljišča. }\end{array}$ \\
\hline Tipologija objektov & $\begin{array}{l}\text { Enodružinska hiša, } \\
\text { postavljena v nizu. }\end{array}$ & $\begin{array}{l}\text { Stanovanjski blok, } \\
\text { mega struktura, } \\
\text { stolpnica; razmeščeni v } \\
\text { geometrijskem redu· }\end{array}$ & $\begin{array}{l}\text { Stanovanjski blok, mega } \\
\text { struktura. }\end{array}$ \\
\hline $\begin{array}{l}\text { Razmerje med } \\
\text { tipologijo in } \\
\text { morfologijo }\end{array}$ & $\begin{array}{l}\text { Tipologija objektov je } \\
\text { podrejena morfologiji } \\
\text { območja. }\end{array}$ & $\begin{array}{l}\text { Tipologija objektov } \\
\text { in morfologija sta v } \\
\text { ravnovesju. }\end{array}$ & $\begin{array}{l}\text { Tipologija objekov je } \\
\text { nadrejena morfologiji } \\
\text { območja. }\end{array}$ \\
\hline $\begin{array}{l}\text { Razmerje med } \\
\text { zasebnim in javnim, } \\
\text { pozidanim in } \\
\text { odprtim prostorom }\end{array}$ & $\begin{array}{l}\text { Jasno razmejen javni, } \\
\text { zasebni in poljavni } \\
\text { prostor. Objekti imajo } \\
\text { prednjo in zadnjo } \\
\text { stran. }\end{array}$ & $\begin{array}{l}\text { Obsežen javni prostor } \\
\text { na račun zasebnega. }\end{array}$ & $\begin{array}{l}\text { Brez zasebnega prostora, } \\
\text { poljavni prostor med } \\
\text { stanovanjskimi objekti. }\end{array}$ \\
\hline Podoba območja & $\begin{array}{l}\text { Podoba klasicističnega } \\
\text { mesta, stanovanjske } \\
\text { hiše omejujejo } \\
\text { prometnico z } \\
\text { drevoredom }\end{array}$ & $\begin{array}{l}\text { Monumentalne grajene } \\
\text { strukture izražajo } \\
\text { kolektivistični duh in } \\
\text { prelom s starim mestom· }\end{array}$ & $\begin{array}{l}\text { Avantgardistični } \\
\text { objekt, moderen in } \\
\text { monumentalen. }\end{array}$ \\
\hline
\end{tabular}

\section{Osnovna ideja paradigem}

Pri Vurnikovem naselju gre za stanovanjsko enoto enakih bivalnih pogojev, kjer je dosežena socialna preglednost in ustvarjeno kvalitetno bivalno okolje. Vsak objekt je neločljiv del naselja; v ustroju naselja je razpoznaven red in podrejenost naselju - celoti.

Soseska Javornik temelji na samozadostnosti stanovanjskega območja ter multiplikaciji istih stanovanjskih enot, poljubno razmeščenih okoli osrednje zelene površine. Hierarhično razmerje med objekti ni razpoznavno, kar asociira na socialno enakost prebivalcev in ustvarjanje enakih bivalnih razmer za vse prebivalce. Organizacija območja se zdi vsaj toliko pomembna kakor oblikovanje območja.

Stožice so zasnovane kot racionalna stavbna enota na razpoložljivem zemljišču. Na račun izkoristka zemljišča so okrnjeni bivalni pogoji (npr. oskrba, zelene površine), čeprav se zdi, da so preference prebivalcev danes drugačne, kot pred leti. Objekti vzbujajo občutek monumentalnosti in atraktivnosti, saj je to eden od načinov, kako povečati atraktivnost stanovanjskega objekta in lokacije. Objekti ne nadgrajujejo obstoječega prostora, temveč v njem prevladujejo.

\section{Razmerje med tipologijo in morfologijo}

Opazno je, da se razmerje med tipom objekta in morfološkim vzorcem stanovanjskega območja skozi čas spreminja. V Vurnikovem naselju morfologija območja prevladuje nad tipologijo objektov, saj so vsi objekti tipološko enaki, morfološki vzorec pa je enak kot 
na širšem območju. Pri enklavi je razmerje povsem obratno - tip objekta je dominanten nad morfologijo območja, med njima ni razpoznavnih povezav. Pri soseski se zdi, da sta razmestitev objektov in tipologija najbolj v ravnovesju. Po eni strani je razmestitev objektov monotona in repetitivna, podobno pa velja tudi za objekte, ki so povsem standardizirani in pripadajo dvema ali trem tipom.

\section{Razmerje med zasebnim in javnim, pozidanim in odprtim prostorom}

Glede tega izstopa predvsem razlika med poljavnim prostorom v Vurnikovem naselju (če ne upoštevamo zasebnega prostora ob stanovanjskih hišah) in pol javnega prostora, ki je omejen samo na funkcionalno zemljišče objekta pri mestu fraktalov. Razlika ni toliko v površini, temveč v funkciji. V Vurnikovem naselju je urejen park, v soseski Javornik dominira zelenica, ki pa je v večjem delu bolj v okras kot v socialni namen, v Stožicah zasebnega prostora ni, razen pol javnih odprti površin med objekti, ki imajo funkcijo komunikacijske poti. Očitno se zasebni prostor umika javnemu.

\section{SKLEP}

Ustroj mest je posledica različnih paradigem oziroma idej o tem, kako mesto urediti. V prispevku smo prikazali tri, ki v največji meri zaznamujejo ustroj in podobo slovenskih mest. Paradigma vrtnega mesta se pojavlja samo v Ljubljani, Mariboru in Celju, v srednje velikih mestih pa zasledimo samo nastavke za njeno kasnejšo realizacijo. Ključna značilnost te paradigme je ulični blok z obcestno pozidavo. Za prostorski razvoj slovenskih mest je daleč najpomembnejša paradigma soseske. Najbrž ni mesta v Sloveniji, ki se ne bi izgrajevalo po tem konceptu. Paradigma je prevladovala v času od 1960 do 1990 (v modifocirani obliki se pojavlja še danes), ko je bil prostorski razvoj mest najintenzivnejši. Prepoznavni element tega obdobja so velika območja stanovanjskih blokov z osnovnimi objekti družbene infrastrukture. Tretja paradigma, uveljavlja se po letu 1990, je paradigma mesta fraktalov. Zanjo je značilna disperzna razmestitev stanovanjskih območij po mestu in po obmestju, visok izkoristek razpoložljivega zemljišča, monumentalnost ter morfološka zaokroženost na majhnem prostoru. Zaenkrat se pojavlja samo v večjih mestih. Z vsako od paradigem nastaja drugačen ustroj mesta, shematično jih lahko ponazorimo približno tako:

Slika 4: Ustroj mest po obravnavanih paradigmah

Figure 4: The structure of cities according to the paradigms dealt with

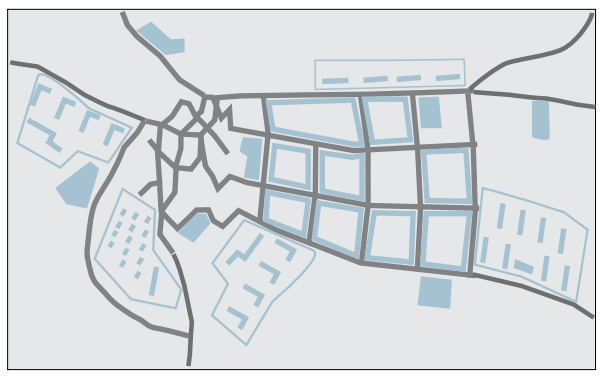


Najpomembnejše ugotovitve primerjave med posameznimi paradigmami lahko strnemo v naslednje zaključke:

- Morfološka povezanost z bližnjo okolico je pri sodobih ureditvah veliko manjša, kakor je bila nekoč.

- $\quad$ V novih prostorskih ureditvah je na račun javnega prostora vedno manj zasebnega.

- $\quad$ Povečuje se izkoristek razpoložljivega zemljišča in s tem gostota urbanih dejavnosti na enoto površine.

- $\quad$ Primarna ideja paradigem se iz socialne sfere vse bolj prestavlja v ekonomistično in oblikovno.

- Oblikovanje objektov in okolice postaja pomembnejše od organizacije dejavnosti na območju.

\section{Literatura}

Broadbent, G., 1990. Emerging Concepts in Urban Space Design. London

Drozg, V. 2004. Spatial development of Slovenian towns in the last decade. DELA 21, Ljubljana. Str. 121 - 129

Fikfak, A., Zbašnik, M. 2002. Preobrati v organizirani več-stanovanjski gradnji - koncepti, tehnologija, financiranje. Urbani izziv. Letnik 13, številka 1. Ljubljana. Str.: 34 - 48

Hall, P. 1988. Cities of Tomorrow. Oxford

Lobnik, U. 2006. Razmetane hiše. Stanovanjske krajine: trendi, perspektive. Ljubljana, 31.3.2006. Oddelek za krajinsko arhitekturo. Biotehnična fakulteta. Str. 11 - 16

Mešl, M., 1986. Urbanizem - ideje in praksa. Soseska Javornik. Ravne na Koroškem

Metzler Philosophie Lexikon. 1999. Stuttgart (MPL)

Mihelič, B. 1983. Urbanistični razvoj Ljubljane. Ljubljana

Mušič, V.B. 1980. Urbanizem - bajke in resničnost. Ljubljana

Peterek, M. 2000. Wohnung, Siedlung, Stadt. Berlin

Pirkovič Kocbek, J. 1982. Izgradnja sodobnega Maribora. Ljubljana

Pogačnik, A. 1996. Nihil nuove sub sole. Arhitektov bilten. Letnik 26, številka 133 - 134. Ljubljana. Str. 64 - 69

Simoneti, M., Vertelj Nared, P. 2006. Analiza večstanovanjske gradnje v Ljubljani. Stanovanjske krajine: trendi, perspektive. Ljubljana, 31.3.2006. Oddelek za krajinsko arhitekturo. Biotehnična fakulteta. Str. $25-33$

Tepina, M. 1996. Prostor in čas urbanizma in Ljubljane urbane. Ljubljana

Verbinc, F. 1967. Slovar tujk. Ljubljana

\section{THREE PARADIGMS OF MODERN DEVELOPMENT OF SLOVENIAN TOWNS}

\section{Summary}

The purpose of this contribution is to show characteristics of paradigms in spatial development of towns in the 20th century. It is based on the analysis of three residential areas, 
built in different time periods and on different conceptual origins. This contribution does not emphasize the history of ideas and regulation of conceptions, but rather familiarization with morphological characteristics as the result of the origins. We are talking about a cultural geographic study, performed in the filed of urban geography.

The recent history of urban city planning shows different concepts - paradigms. We chose three, which we believe to be the most relevant and characteristic for the above mentioned three phases of spatial development of Slovene towns. Those are:

- completion of the existing structures, built between 1920s and 1950s, illustrated by the paradigm of a garden city (based on the example of Vurnik residential area in Maribor)

- $\quad$ expansion to new areas in the outskirts between 1950s and 1990s, illustrated by the paradigm of Javornik neighborhood in Ravne na Koroškem

- $\quad$ filling up the existing structures after the year 1990 (based on the residential area Stožice in Ljubljana) - paradigm of a fractal city

The point of urban-geographic comprehension of paradigms, connected to development of towns is not describing the ground plans of individual areas but rather uncovering the idea that served as a basis for projection and planning of residential areas and consequently towns. What matters in this context is the relationship between the morphological pattern of the area and the surroundings as well as morphological characteristics of discussed area. Discussed paradigms are compared at two levels with the following questions:

At the level of the town as a whole or parts of the town

- $\quad$ is there a spatial or functional relationship between the residential area and the town as a whole, which are the key elements of this relationship, what is the relation to historic heritage of the town?

- what conception or idea follows the individual paradigm, what is its essence?

- how are individual paradigms incorporated into the spatial growth of the town?

At the level of the area and near surroundings

- does the arrangement of buildings follow the morphological pattern of the near surroundings?

- what social needs are covered in the area?

- what is the relationship between the private and the public space, what are the open spaces intended for?

The structure of towns was changing and shaping through individual paradigms. The most important characteristics of a garden town is a street block with buildings alongside the street. This can be found in Ljubljana, Maribor and Celje. Medium-sized towns only show the basis for a future realization. The most important paradigm for spatial development of Slovene towns is the neighborhood paradigm. There is probably not a single town in Slovenia that was not built upon this concept. This paradigm was especially in use between 1960s and 1990s, when spatial development of towns was at its peak. The most recognizable features of this era are large residential areas with blocks of flats that include buildings of social infrastructure. The third paradigm, in use after the year 1990, is a fractal town. Its main characteristic is dispersed arrangement of residential areas throughout the town and its surroundings, a good usage of available land, monumental architecture and morphological unity. 